\title{
Denitrification, nitrogen fixation, community primary productivity and inorganic-N and oxygen fluxes in an intertidal Zostera noltii meadow
}

\author{
David T. Welsh ${ }^{1,2, *}$, Marco Bartoli ${ }^{1}$, Daniele Nizzoli ${ }^{1}$, Giuseppe Castaldelli ${ }^{3}$, \\ Stéphane A. Riou' ${ }^{2}$ Pierluigi Viaroli ${ }^{1}$
}

\begin{abstract}
${ }^{1}$ Dipartimento di Scienze Ambientali, Università degli Studi di Parma, Parco Area delle Scienze 33A, 43100 Parma, Italy
${ }^{2}$ Laboratoire d'Ocèanographie, Université de Bordeaux I, 2 rue Professeur Jolyet, 32100 Arcachon, France

${ }^{3}$ Dipartimento di Biologia Evolutiva, Università di Ferrara, Via L. Borsari 46, 44100 Ferrara, Italy
\end{abstract}

\begin{abstract}
Rates of denitrification, N-fixation, gross community primary productivity, inorganic-N and oxygen fluxes were determined in February, May and October 1997 in an intertidal Zostera noltii meadow of the Bassin d'Arcachon, French Atlantic coast. Rates of gross community primary productivity were high, 0.09 to $0.40 \mathrm{~g} \mathrm{C} \mathrm{m}^{-2} \mathrm{~h}^{-1}$; high P:R ratios of 1.64 to 2.82 define the system as highly autotrophic and indicate significant losses of carbon via export and/or burial of biomass. Fluxes of DIN, nitrate and ammonium were large $\left(-0.8\right.$ to $-2.4,-0.1$ to -2.2 and -0.1 to $-0.7 \mathrm{mmol} \mathrm{N} \mathrm{m} \mathrm{N}^{-2}$, respectively) and always directed towards the plants/sediment during both light and dark incubations. The contributions of nitrate, nitrite and ammonium to total DIN fluxes reflected their relative abundance in the water column, indicating that there was no assimilatory selection of inorganic-N sources by the plants. The DIN fluxes were dominated by the N-assimilation activity of the plants even during dark incubations, as removal of the plant shoots prior to incubations essentially abolished nitrate fluxes and reversed ammonium fluxes, resulting in substantial effluxes. Thus, inorganic$\mathrm{N}$ fluxes were controlled principally by the $Z$. noltii and epiphyte biomasses and their primary productivity, rather than the water column concentrations of DIN. Surprisingly, the plant community showed a high dark assimilation activity for inorganic-N, and differences in light and dark fluxes of DIN, nitrate and ammonium were never significant. Data indicate that, whilst DIN fluxes could supply the $\mathrm{N}$-demand of primary production in spring, the plants became increasingly dependent upon sediment $\mathrm{N}$-pools, $\mathrm{N}$-fixation and internal N-reserves through summer into autumn. Denitrification rates determined by the ${ }^{15} \mathrm{~N}$-isotope pairing technique were extremely low, ranging between 2 and $6 \mu \mathrm{mol} \mathrm{N} \mathrm{m} \mathrm{N}^{-2} \mathrm{~h}^{-1}$. Rates of denitrification of nitrate diffusing from the overlying water were consistently below $2 \mu \mathrm{mol} \mathrm{N} \mathrm{m} \mathrm{N}^{-2} \mathrm{~h}^{-1}$ during both light and dark incubations and represented only 0.1 to $0.7 \%$ and 0.2 to $1.3 \%$ of the total light and dark nitrate fluxes, respectively. Similarly, rates of denitrification coupled to nitrification were consistently low, probably due to the competition between nitrifying bacteria and the $Z$. noltii roots for ammonium. N-fixation rates varied between 4 and $17 \mu \mathrm{mol} N$ $\mathrm{m}^{-2} \mathrm{~h}^{-1}$ and were substantially greater than N-losses via denitrification in all seasons, with net $\mathrm{N}_{2}$ inputs ranging between 2.5 and $14.6 \mu \mathrm{mol} \mathrm{N} \mathrm{m} \mathrm{N} \mathrm{h}^{-1}$ and 0.5 and $3.8 \mu \mathrm{mol} \mathrm{N} \mathrm{m}^{-2} \mathrm{~h}^{-1}$, during light and dark incubations. Overall, our data demonstrate that the $Z$. noltii meadows represent a highly conservative environment for nitrogen, where the $\mathrm{N}$-cycle is dominated by the primary productivity of the plant community and the associated assimilatory demand for fixed- $\mathrm{N}$ to support this productivity. Conversely, N-losses via denitrification are extremely low and are more than balanced by N-inputs from $\mathrm{N}$-fixation. Thus, in this macro-tidal lagoon, export of nitrogen as plant biomass and/or N-burial in the sediments are probably the major loss mechanisms for anthropogenic $\mathrm{N}$-inputs.
\end{abstract}

KEY WORDS: Denitrification · Nitrification $\cdot$ Nitrogen fixation $\cdot$ Inorganic nitrogen fluxes $\cdot$ Primary productivity $\cdot$ Nitrogen assimilation $\cdot$ Seagrass $\cdot$ Sediments

* Present address: Dipartimento di Scienze Ambientali, Università degli Studi di Parma, Viale delle Scienze, 43100 Parma, Italy. E-mail: dave@eagle.dsa.unipr.it

\section{INTRODUCTION}

Seagrass meadows exhibit substantial rates of both primary and secondary productivity, support diverse 
epiphyte and faunal communities and are important nursery environments for many fish species (Stevenson 1988, Moriarty et al. 1990, Tomasko \& Lapointe 1991, Gotceitas et al. 1997). In contrast to other marine macrophytes, seagrasses possess an extensive root and rhizome system, and are able to exploit both water column and sediment nutrient pools (Short \& McRoy 1984, Moriarty \& Boon 1989, Pedersen \& Borum 1992, Hemminga et al. 1994). The activity of the plants and their high $\mathrm{N}$-demand for primary production may also modify N-cycling in seagrass ecosystems (Moriarty \& Boon 1989, Caffrey \& Kemp 1990, 1992). For example, many studies have demonstrated high rates of N-fixation in the rhizosphere sediments, which are coupled to the photosynthetic activity of the plants via the exudation of fixed carbon by the root system (see Welsh 2000 for review). Similarly, several authors have reported high rates of coupled nitrification/denitrification associated with oxygen release by the plant roots (Iizumi et al. 1980, Caffrey \& Kemp 1990, 1991, Caffrey \& Kemp 1992, Shieh \& Yang 1997, Pedersen et al. 1998), although, in contrast, other studies have reported low rates (e.g. Rysgaard et al. 1996, RisgaardPetersen et al. 1998, Ottosen et al. 1999). Thus, in the rhizosphere, rates of coupled nitrification/denitrification may be dependent upon the relative influences of oxygen release by the plant roots and competition between the roots and nitrifying and denitrifying bacteria for ammonium, nitrite and nitrate. Indeed, Blackburn et al. (1994) have reported significant diurnal variations in porewater ammonium pools and denitrification rates in a Halodule beaudetti meadow, with high dawn ammonium pools and denitrification rates declining during the day, indicating that $\mathrm{N}$-assimilation by the plant roots regulates porewater ammonium pools and thus, indirectly, rates of nitrification and denitrification in the rhizosphere.

In pristine seagrass ecosystems, primary productivity is generally considered to be N-limited, as evidenced by the high rates of plant associated $\mathrm{N}$-fixation and the stimulation of growth rates and standing crops following fertiliser additions (Harlin \& Thorn-Miller 1981, Short 1987, Capone 1988, O'Donohue et al. 1991, Welsh et al. 1996). However, in recent decades, there have been world-wide often catastrophic losses of seagrass habitats, which have commonly been associated with increased nutrient loads (see Duarte 1995, Hemminga 1998 and references therein). In general, increasing levels of eutrophication result in a shift from primary producer communities dominated by slowgrowing rooted macrophytes to systems dominated by fast-growing ephemeral macro- and micro-algae (Cambridge \& McComb 1984, Neuendorfer \& Kemp 1993, Duarte 1995, Hemminga 1998). Whilst these community changes have been correlated with de- creased light availability due to increases in epiphyte loads and primary production in the water column (Sand-Jensen \& Borum 1991, Burkholder et al. 1994, Short et al. 1995), they are not a gradual process, but rather occur as sudden stepwise shifts which are not directly linked to changes in nutrient loads (Cambridge \& McComb 1984, Duarte 1995) and may even be concomitant with nutrient limitation in some cases (van Lent et al. 1995). Thus, a profound understanding of the $\mathrm{N}$-dynamics of seagrass beds is essential for the sustainable management of these valuable ecosystems.

The Bassin d'Arcachon is a large macro-tidal coastal lagoon $\left(155 \mathrm{~km}^{2}\right)$ on the Atlantic coast of France, more than half of the surface area of the Bassin is composed of intertidal mudflats of which $>70 \mathrm{~km}^{2}$ are colonised by the seagrass Zostera noltii Hornem. In recent decades, the Bassin has been subject to increasing nitrate loads due to forest areas in the catchment being replaced by intensive maize farming (Auby et al. 1994). These changes have resulted in annual blooms of the ephemeral macro-algae Enteromorpha clathrata during the 1970s and early 1980s and more recently Monostroma obscurum (Auby et al. 1994), although up to the present there have been no decreases in the area occupied by the seagrasses (Auby 1991, Auby \& Labourg 1996). In the current study, we investigated $\mathrm{N}$-dynamics and primary productivity in a typical intertidal Z. noltii meadow of the Bassin.

\section{MATERIALS AND METHODS}

Sampling site and sampling methods. Samples were collected in February, May and October 1997 at ROBUST Station A (see Welsh et al. 1996), which is situated in an extensive intertidal seagrass meadow of the Ile aux Oiseaux in the central portion of the Bassin $d^{\prime}$ Arcachon $\left(44^{\circ} 40^{\prime} \mathrm{N}, 1^{\circ} 10^{\prime} \mathrm{W}\right)$. Cores were hand collected at low tide using plexiglass core tubes of varying diameter, transported to the laboratory within $1 \mathrm{~h}$ and stored under natural light and temperature conditions in a 6001 mesocosm tank, which was flushed with natural seawater from the Bassin at a rate of approximately $200 \mathrm{l} \mathrm{h}^{-1}$. Cores were stored maximally for $36 \mathrm{~h}$ before the experiments.

Flux measurements. Sediment cores of approximately $15 \mathrm{~cm}$ length were collected using $40 \times 20 \mathrm{~cm}$ (internal diameter) plexiglass core tubes; at the laboratory, a small electrical aquarium pump was placed inside each core to prevent the establishment of concentration gradients within the core and to mix the water column with the overlying water in the mesocosm tank. Cores were equilibrated for at least $12 \mathrm{~h}$ before flux or denitrification determinations. To initiate 
flux measurements, the water level in the mesocosm tank was lowered to below that of the cores, time 0 samples collected for oxygen and inorganic nutrients and the cores closed with floating transparent plexiglass lids. Triplicate cores were incubated under either natural light or dark (double wrapped in aluminium foil) conditions for 1 to $2 \mathrm{~h}$, depending on the oxygen consumption/production rates determined in preliminary incubations, in order to maintain oxygen concentrations within $\pm 20 \%$ of the initial air saturation concentration. At the end of the incubation the aquarium pump was stopped, the floating lids removed and final time samples for oxygen and inorganic nutrients collected immediately.

To compare flux rates in the presence of entire and defoliated plants, cores of approximately $15 \mathrm{~cm}$ length were collected in $40 \times 8 \mathrm{~cm}$ (internal diameter) plexiglass core tubes from areas where the Zostera noltii shoots had been cut. At the laboratory, a magnetic stirrer was fixed inside each core $\sim 5 \mathrm{~cm}$ above the sediment surface, and the cores were placed in an incubation tank containing a central motor turning 2 large magnets to drive the individual magnetic stirrers. Thereafter, the procedure for determination of fluxes was as described for the $20 \mathrm{~cm}$ cores.

Flux rates of oxygen, nitrite, nitrate and ammonium were calculated using the general flux equation:

$$
F=\left(C_{0}-C_{T}\right) V / A \times T
$$

where $C_{0}$ and $C_{T}$ are the species concentrations at time 0 and time $T$, respectively; $V$ is the volume of water in the core; $A$ is the sediment surface area and $T$ the incubation time.

Determination of denitrification rates. Total denitrification $\left(D_{14}\right)$, denitrification of nitrate diffusing from the water column $\left(D_{\mathrm{W}}\right)$ and coupled nitrification/denitrification $\left(D_{\mathrm{N}}\right)$ rates were determined by the ${ }^{15} \mathrm{~N}$-isotope pairing technique of Nielsen (1992), using the same $40 \times 20 \mathrm{~cm}$ cores as for flux measurements, following a standard addition of $30 \mu \mathrm{M}{ }^{15} \mathrm{~N}$-nitrate $\left(99{ }^{15} \mathrm{~N}\right.$ at. \%) to the water column. The actual ${ }^{15} \mathrm{~N}$-nitrate concentration was determined by the difference between the water column nitrate concentration prior to and after the addition of ${ }^{15} \mathrm{~N}$-nitrate. Cores were incubated under natural light or dark conditions as described for flux determinations, for an incubation period determined from oxygen consumption/production rates such that the water column oxygen concentration remained at $\pm 20 \%$ of the initial concentration, which is a prerequisite of the isotope pairing technique (Nielsen 1992). At the end of the incubations, activities were stopped by the addition of $7 \mathrm{M} \mathrm{ZnCl}_{2}$ to a final concentration of $10 \mathrm{mM}$. The cores were then gently slurried using a metal bar in order to mix the dissolved $\mathrm{N}_{2}$ pools in the water column and sediment porewater, and subsamples of the slurry were transferred to gastight, $12 \mathrm{ml}$ glass vials (Exetainer, Labco, High Wycombe, UK), fixed with $100 \mu l 7 \mathrm{M} \mathrm{ZnCl}_{2}$ and stored at $4^{\circ} \mathrm{C}$. Samples were analysed within 2 to $3 \mathrm{wk}$ for ${ }^{14} \mathrm{~N}^{15} \mathrm{~N}$ and ${ }^{15} \mathrm{~N}^{15} \mathrm{~N}-\mathrm{N}_{2}$ using a Europa dual inlet mass spectrometer (Europa, Crewe, UK), as previously described (Rysgaard et al. 1995), and production rates of the isotope pairs were calculated from the combined volume of the water column and porewater (calculated by multiplying the sediment volume by the porosity, determined as loss of dry weight after drying at $90^{\circ} \mathrm{C}$ for $24 \mathrm{~h}$ ). Denitrification rates were estimated from the production rates using the equations derived by Nielsen (1992):

$$
\begin{gathered}
D_{15}=p\left({ }^{14} \mathrm{~N}^{15} \mathrm{~N}\right)+2 p\left({ }^{15} \mathrm{~N}^{15} \mathrm{~N}\right) \\
D_{14}=p\left({ }^{14} \mathrm{~N}^{15} \mathrm{~N}\right) / 2 p\left({ }^{15} \mathrm{~N}^{15} \mathrm{~N}\right) \times D_{15}
\end{gathered}
$$

where $D_{15}$ and $D_{14}$ are the rates of denitrification of added ${ }^{15} \mathrm{NO}_{3}{ }^{-}$and ambient ${ }^{14} \mathrm{NO}_{3}{ }^{-}$, respectively, and $p\left({ }^{14} \mathrm{~N}^{15} \mathrm{~N}\right)$ and $p\left({ }^{15} \mathrm{~N}^{15} \mathrm{~N}\right)$ are the production rates of the $2{ }^{15} \mathrm{~N}$-labelled $\mathrm{N}_{2}$ species, ${ }^{14} \mathrm{~N}^{15} \mathrm{~N}$ and ${ }^{15} \mathrm{~N}^{15} \mathrm{~N}$, respectively. The calculated rate $D_{15}$ expresses denitrification of added ${ }^{15} \mathrm{~N}$-nitrate, whilst $D_{14}$ expresses the total in situ denitrification rate of ${ }^{14} \mathrm{~N}$-nitrate. The proportion of $D_{14}$ based on nitrate diffusing from the water column $\left(D_{\text {W }}\right)$ was calculated from $D_{15}$ and the ${ }^{15} \mathrm{~N}$ enrichment of the water column nitrate pool as

$$
D_{\mathrm{W}}=D_{15}\left[{ }^{14} \mathrm{NO}_{3}{ }^{-}\right]_{\mathrm{W}} /\left[{ }^{15} \mathrm{NO}_{3}{ }^{-}\right]_{\mathrm{W}}
$$

where $\left[{ }^{14} \mathrm{NO}_{3}{ }^{-}\right]_{\mathrm{W}}$ and $\left[{ }^{15} \mathrm{NO}_{3}{ }^{-}\right]_{\mathrm{W}}$ are the concentrations of unlabelled and ${ }^{15} \mathrm{~N}$-labelled nitrate in the water column.

In situ rates of denitrification coupled to nitrate produced by nitrification activity in the sediment $\left(D_{\mathrm{N}}\right)$ were calculated by the difference:

$$
D_{\mathrm{N}}=D_{14}-D_{\mathrm{W}}
$$

However, due to the dependence that labelled nitrate diffuses from the water column to the denitrification zone, in seagrass-colonised sediments the isotope pairing technique can only be considered to measure denitrification in the surficial sediments. Coupled nitrification/denitrification occurring in the deeper sediments in microzones around the plant roots would not be measured, since these sites are isolated from the diffusion zone of the added ${ }^{15} \mathrm{~N}$-nitrate (Nielsen 1992).

Determination of nitrogen fixation rates. $\mathrm{N}$-fixation rates were determined as acetylene reduction rates following addition of acetylene-saturated seawater to a final concentration of $10 \%(\mathrm{v} / \mathrm{v})$ to the water column and sediment porewater of sealed sediment cores containing intact plants. The cores were incubated for $6 \mathrm{~h}$ under natural light or dark (double wrapped in aluminium foil) conditions, and ethylene production rates were determined by gas chromotography 
(see Welsh et al. 1997 for details of the method and analysis). Acetylene reduction rates were converted into $\mathrm{N}$-fixation rates using the theoretical ratio based on the provision of reducing equivalents, such that the reduction of $3 \mathrm{~mol}$ of acetylene to ethylene is equivalent to the reduction of $1 \mathrm{~mol}$ of $\mathrm{N}_{2}$ to $2 \mathrm{~mol}$ of $\mathrm{NH}_{3}$. This ratio, however, can be highly variable in marine sediments, although previous inter-calibrations between the acetylene reduction technique and ${ }^{15} \mathrm{~N}_{2}$ fixation in seagrass meadows are in very close agreement with the theoretical ratio (Capone 1988, O'Donohue et al. 1991).

Determination of Zostera noltii biomass. Five replicate cores (18 cm internal diameter) were hand collected in the field. At the laboratory, the cores were sieved through a $1 \mathrm{~mm}$ mesh under running seawater to remove the sediment and hand sorted into living shoot, root and rhizome biomass. The biomasses were rinsed briefly with tap water to remove salts and oven dried at $70^{\circ} \mathrm{C}$ for $24 \mathrm{~h}$.

Analytical techniques. Dissolved oxygen concentrations were determined by Winkler titration (APHA 1975), ammonium concentrations were measured by the indophenol-blue method (Koroleff 1970), nitrite was measured using a Technicon autoanalyser II following diazotation (APHA 1975), nitrate was determined as nitrite by the same method, following reduc-
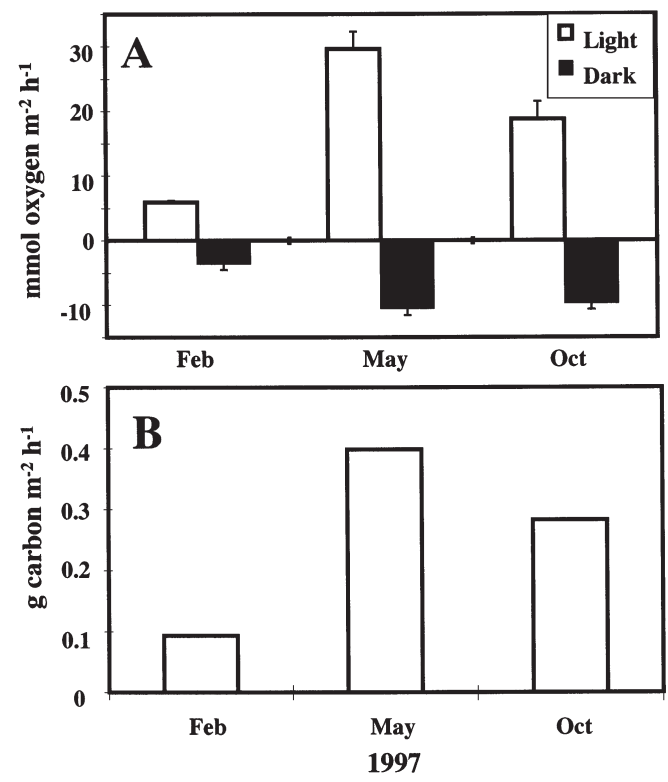

Fig. 1. (A) Light and dark oxygen fluxes in the Zostera noltiicolonised sediments in February, May and October 1997. Error bars represent the standard error of the mean $(n=3)$. (B) Gross system primary productivity, estimated as the difference between the mean light and dark oxygen fluxes and expressed in carbon equivalents using a conversion factor of $0.31 \mathrm{~g} \mathrm{C} \mathrm{g}^{-1} \mathrm{O}_{2}$ (Schramm et al. 1984) tion over cadmium columns, and data were corrected for the ambient nitrite concentration.

Statistical analysis. Normality of data was assumed, and homoscedasticity was confirmed using the Cochran test. Data were analysed by ANOVA, with an a posteriori comparison of the means performed using the $t$-method (Sokal \& Rohlf 1995). When necessary for homogeneity, the data were log transformed prior to analysis.

\section{RESULTS}

\section{General observations}

Following a period of hard frosts during January 1997, which damaged much of the above-ground biomass of the Zostera noltii bed, during the February sampling programme the sampling station was essentially covered by a layer of matted dead seagrass leaves, which were heavily colonised by micro-algae, with a high dominance of diatom species (E. Lemaire pers. comm.). Below this mat, there was a lush growth of fresh $Z$. noltii shoots sprouting from the undamaged rhizomes.

In May, the Zostera noltii bed consisted of an even meadow of healthy, relatively young shoots with few macro-epiphytes. In contrast, during the final sampling in October, much of the above-ground biomass appeared to be moribund, and the tips of the older, outer leaves were brown and sparsely colonised by fibrous epiphytes. Shortly after this sampling, the plants began to shed their leaves, and by mid-November the above-ground biomass had decreased to approximately half of the maximum summer value (D.T.W. unpubl. data). During all 3 sampling periods, the bulk of the root and rhizome biomass was located within the upper 2 to $3 \mathrm{~cm}$ of sediment, although a few roots did penetrate to a maximal depth of approximately $5 \mathrm{~cm}$.

\section{Oxygen fluxes and gross primary productivity}

Dark sediment oxygen demands ranged between $-3.6 \pm 1.0$ in February and $-10.5 \pm 1.0 \mathrm{mmol} \mathrm{m}^{-2} \mathrm{~h}^{-1}$ in May (Fig. 1A) and correlated well with the seasonal changes in the sediment temperature (Table 1). During light incubations, the oxygen fluxes were dominated by the photosynthetic activity of the $Z$. noltii and their epiphytes, with a maximum production of $29.6 \pm$ $2.7 \mathrm{mmol} \mathrm{O}_{2} \mathrm{~m}^{-2} \mathrm{~h}^{-1}$ measured in May 1997. In all the tested seasons, the sampling site would be considered highly autotrophic according to the classification of Rizzo et al. (1996), as rates of oxygen evolution in the 
Table 1. Biomasses of Zostera noltii, sediment temperature and water column concentrations of inorganic nitrogen species at Sampling Station A in February, May and October 1997. Figures in parentheses for biomass determinations represent 1 SD $(\mathrm{n}=5)$

\begin{tabular}{|c|c|c|c|c|c|c|c|}
\hline \multirow[t]{2}{*}{ Sample period } & \multirow{2}{*}{$\begin{array}{c}\text { Temperature } \\
\left({ }^{\circ} \mathrm{C}\right)\end{array}$} & \multicolumn{3}{|c|}{ Zostera noltii biomasses ( $\mathrm{g}$ dry wt $\mathrm{m}^{-2}$ ) } & \multicolumn{3}{|c|}{ Inorganic nutrients $(\mu \mathrm{M})$} \\
\hline & & Shoots & Roots and rhizome & Total & $\mathrm{NH}_{4}^{+}$ & $\mathrm{NO}_{3}^{-}$ & $\mathrm{NO}_{2}$ \\
\hline Feb & 12 & $35.7(22.3)$ & $24.7(17.1)$ & $60.5(38.2)$ & 3.4 & 22.4 & 1.6 \\
\hline May & 22 & $86.0(16.8)$ & $63.0(14.2)$ & $148.9(30.6)$ & 2.3 & 10.4 & 0.2 \\
\hline Oct & 17 & $87.8(12.8)$ & $66.4(24.7)$ & $154.2(28.1)$ & 7.9 & 1.7 & 0.7 \\
\hline
\end{tabular}

light were far greater than dark consumption rates, with respiration:photosynthesis (P:R) ratios of 1.64, 2.82 and 1.93 determined in February, May and October, respectively.

Rates of gross system primary productivity calculated from the differences between light and dark oxygen fluxes were large, varying from 9.5 and $28.5 \mathrm{mmol}$ $\mathrm{O}_{2} \mathrm{~m}^{-2} \mathrm{~h}^{-1}$ in February and October, respectively, to a summer peak of $40.1 \mathrm{mmol} \mathrm{O}_{2} \mathrm{~m}^{-2} \mathrm{~h}^{-1}$ recorded in May. Conversion of these rates into carbon equivalents using a conversion factor of $0.31 \mathrm{~g} \mathrm{C} \mathrm{g}^{-1} \mathrm{O}_{2}$ (Schramm et al. 1984) yields rates of gross community primary productivity of $0.09,0.40$ and $0.28 \mathrm{~g} \mathrm{C} \mathrm{m}^{-2} \mathrm{~h}^{-1}$, respectively, in February, May and October (Fig. 1B).

\section{Inorganic nitrogen fluxes}

Fluxes of dissolved inorganic nitrogen (DIN), ammonium and nitrate during both light and dark incubations were consistently directed towards the plant/sediment system with DIN, nitrate and ammonium fluxes varying between -0.8 and $-2.4,-0.1$ and -2.2 and -0.1 and $-0.7 \mathrm{mmol} \mathrm{N} \mathrm{m}^{-2} \mathrm{~h}^{-1}$, respectively (Fig. 2). Nitrite fluxes were small ( $>0.05 \mathrm{mmol} \mathrm{N} \mathrm{m}^{-2} \mathrm{~h}^{-1}$ ), but again were directed towards the plants/sediment, with the exception of May 1997, when there was a small efflux of nitrite during the dark incubation (data not shown). Although, there was a tendency, especially in May, for higher fluxes of DIN, nitrate and ammonium during light compared to dark incubations, these differences were never significant for any of the fluxes in any of the months $(\mathrm{p}>0.05)$.

The composition of the total DIN fluxes followed closely the relative availability of the inorganic $\mathrm{N}$ species in the water column during both light and dark incubations in all tested seasons (Table 2). Thus, DIN fluxes were dominated by the nitrate component in both February and May, approximately 83 and $90 \%$ of total DIN flux, when water column nitrate concentrations were high compared to those of ammonium and conversely by ammonium fluxes in October, approximately $80 \%$ of total DIN flux, when water column nitrate concentrations were relatively low compared to those of ammonium (Fig. 2, Tables 1 \& 2). However, the overall magnitude of the fluxes appears not to be dependent on the total water column DIN concentrations. For example, DIN fluxes measured during light incubations in May were more than 2.6-fold greater than those determined in February (Fig. 2A), although total water column DIN concentrations during the later period were $<50 \%$ of those during the former (Table 1).

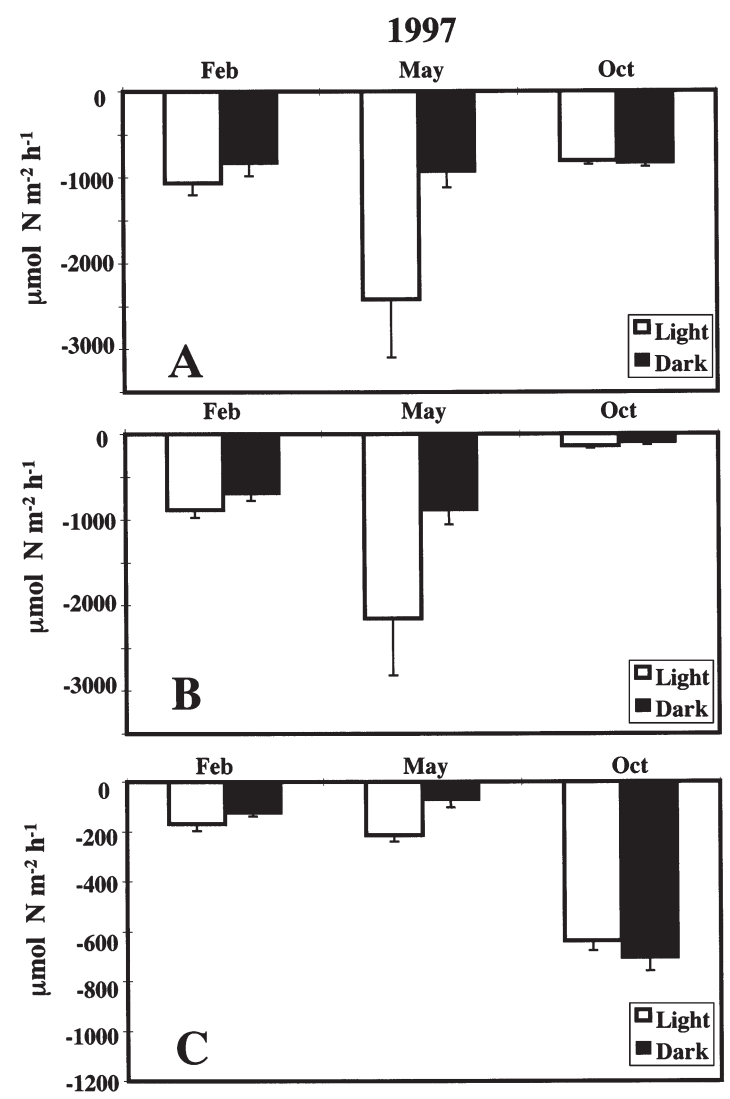

Fig. 2. Light and dark fluxes of: (A) total dissolved inorganic nitrogen (DIN); (B) nitrate; and (C) ammonium in Zostera noltii-colonised sediments, in March, May and October 1997. Error bars represent SE $(n=3)$. Please note the difference in scale for the ammonium fluxes (C) 
Table 2. Relative \% composition of water column dissolved inorganic nitrogen (DIN) pools and light and dark fluxes of DIN

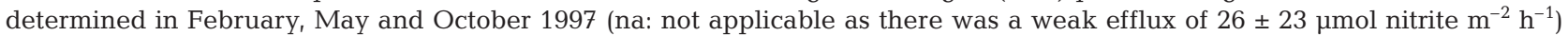

\begin{tabular}{|c|c|c|c|c|c|c|c|c|c|}
\hline \multirow[t]{2}{*}{$\mathrm{N}$-species } & \multicolumn{3}{|c|}{ Water column DIN } & \multicolumn{3}{|c|}{ Light DIN flux } & \multicolumn{3}{|c|}{ Dark DIN flux } \\
\hline & Feb & May & Oct & Feb & May & Oct & Feb & May & Oct \\
\hline Nitrate & 81.8 & 80.4 & 16.8 & 82.3 & 89.0 & 17.4 & 82.8 & $92.4^{\mathrm{a}}$ & 12.5 \\
\hline Nitrite & 5.8 & 1.5 & 6.3 & 1.9 & 2.2 & 3.9 & 2.2 & NA & 3.4 \\
\hline Ammonium & 12.4 & 18.1 & 77.1 & 15.8 & 8.8 & 78.7 & 15.0 & $7.6^{\mathrm{a}}$ & 84.1 \\
\hline
\end{tabular}

Assimilation of inorganic- $\mathrm{N}$ by the Zostera noltii and their associated epiphytes had a major influence on overall DIN fluxes, with the period of maximum DIN fluxes in May corresponding with the highest standing crop of $Z$. noltii and the maximum recorded gross community primary productivity (Table 1, Fig. 1B). Indeed, in October, in cores where the $Z$. noltii shoots had been
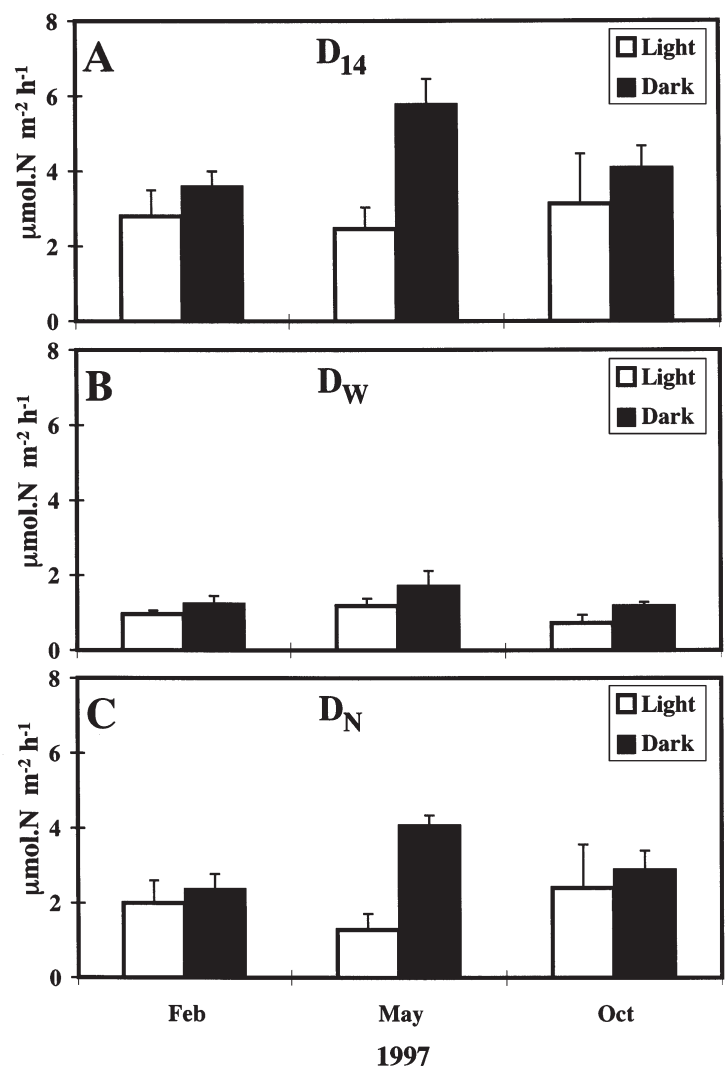

Fig. 3. Light and dark rates of denitrification determined in Zostera noltii colonised sediments in February, May and October 1997: (A) total denitrification $\left(D_{14}\right)$; (B) denitrification of nitrate diffusing from the overlying water $\left(D_{\mathrm{W}}\right)_{\mathrm{i}}$ and (C) denitrification coupled to nitrification in the sediment $\left(D_{\mathrm{N}}\right)$. Error bars represent SE $(\mathrm{n}=3)$ removed, nitrate fluxes were essentially abolished compared to whole plant incubations, and ammonium fluxes were reversed (Table 3), with mean effluxes of $0.08 \pm 0.07$ and $0.49 \pm 0.15 \mathrm{mmol} \mathrm{N} \mathrm{m}^{-2} \mathrm{~h}^{-1}$ during light and dark incubations, respectively, compared to mean net influxes of $-0.64 \pm 0.09$ and $-0.71 \pm 0.11 \mathrm{mmol} \mathrm{N}$ $\mathrm{m}^{-2} \mathrm{~h}^{-1}$ in the corresponding incubations with whole plants (Fig. 2C).

\section{Denitrification and nitrogen fixation rates and net $\mathbf{N}_{2}$ fluxes}

Rates of total denitrification $\left(D_{14}\right)$ measured using the isotope pairing technique under both light and dark conditions were extremely low, with all measured rates within the range of 2 to $6 \mu \mathrm{mol} \mathrm{N} \mathrm{m}^{-2} \mathrm{~h}^{-1}$ (Fig. 3A), but seasonal variations were not significant ( $p>0.05)$, during either light or dark incubations. Rates of denitrification of nitrates diffusing from the overlying water column $\left(D_{\mathrm{W}}\right)$ were consistently below $2 \mu \mathrm{mol}$ $\mathrm{N} \mathrm{m}^{-2} \mathrm{~h}^{-1}$ (Fig. 3B), and represented between 23 and $48 \%$ (seasonal mean $33 \%$ ) of the total denitrification. Generally, rates of $D_{\mathrm{W}}$ were approximately $50 \%$ greater during dark compared to light incubations throughout the year (Fig. 3B), but these differences were not significant for any of the individual months

Table 3. Light and dark fluxes of ammonium, nitrate and nitrite determined in October 1997 in cores where the Zostera noltii leaves had been removed prior to the incubations. Data represent the means of 5 replicate determinations, and figures in parentheses indicate $1 \mathrm{SD}(\mathrm{n}=5)$. A negative flux rate indicates that the flux was from the water column towards the sediment

\begin{tabular}{|lcc|}
\hline N-species & \multicolumn{2}{c|}{ Flux rate $\left(\mu \mathrm{mol} \mathrm{m}^{-2} \mathrm{~h}^{-1}\right)$} \\
& Light incubation & Dark incubation \\
\hline Ammonium & $84(70)$ & $493(146)$ \\
Nitrate & $-3(26)$ & $6(23)$ \\
Nitrite & $8(6)$ & $8(6)$ \\
\hline
\end{tabular}




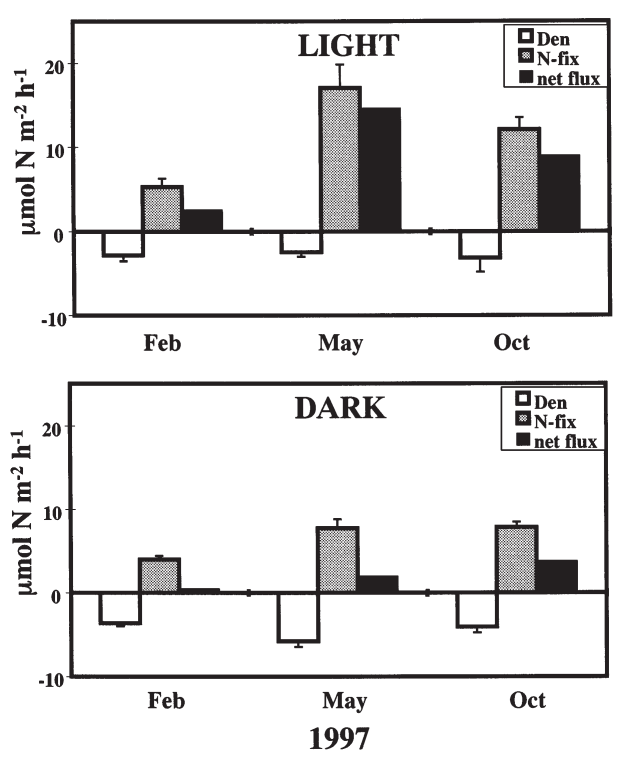

Fig. 4. Light and dark rates of total denitrification (Den), Nfixation ( $\mathrm{N}$-fix) and the net $\mathrm{N}_{2}$ flux (net flux; $\mathrm{N}$-fixation - total denitrification) in Zostera noltii-colonised sediments in February, May and October 1997. Error bars represent SE (n = 5 for N-fixation measurements and 3 for denitrification measurements)

(p $>0.05$ ) and neither light nor dark rates of $D_{\mathrm{W}}$ showed any significant seasonal trends ( $p>0.05)$, even though the water column nitrate concentrations varied between 22.4 and $1.7 \mu \mathrm{M}$ between February and October (Table 1). Rates of denitrification coupled to nitrification activity in the sediments $\left(D_{\mathrm{N}}\right)$ were generally somewhat higher than those of $D_{\mathrm{W}}$, ranging between 1 and $4 \mu \mathrm{mol} \mathrm{N} \mathrm{m}^{-2} \mathrm{~h}^{-1}$ (Fig. $3 \mathrm{C}$ ), and tended to be greater during dark compared to light incubations, although this difference was only significant in May $(\mathrm{p}<0.05)$.

In contrast to denitrification measurements, rates of N-fixation, determined as acetylene reduction rates, showed a highly significant peak in May during both light and dark incubations $(\mathrm{p}<0.01)$, with rates of 17.0 and $7.7 \mu \mathrm{mol} \mathrm{N} \mathrm{m}^{-2} \mathrm{~h}^{-1}$ recorded during light and dark incubations, respectively. $\mathrm{N}$-fixation rates during light incubations were also significantly $(p<0.01)$ greater than those during dark incubations in both May and October, due to the coupling of N-fixation activity in the rhizosphere to the photosynthetic activity of the Zostera noltii in this ecosystem (Welsh et al. 1996, 1997). During both light and dark incubations, due to the relatively high rates of $\mathrm{N}$-fixation compared to the denitrification rates, net inputs of molecular nitrogen to the sediment were measured in all the seasons, of from 2.5 to 14.6 and 0.5 to $3.8 \mu \mathrm{mol} \mathrm{N}$ $\mathrm{m}^{-2} \mathrm{~h}^{-1}$ during light and dark incubations, respectively (Fig. 4).

\section{DISCUSSION}

The Zostera noltii meadows exhibited high rates of gross system primary productivity, estimated to be equivalent to $0.09,0.40$ and $0.28 \mathrm{~g} \mathrm{C} \mathrm{m}^{-2} \mathrm{~h}^{-1}$ in February, May and October 1997, respectively (Fig. 1). Using data on mean monthly day lengths and mean hours of insolation per day to define maximum and minimum photosynthetic periods (Auby 1991), these rates would be equivalent to from 0.4 to $0.9,2.8$ to 6.0 and 1.5 to $3.6 \mathrm{~g} \mathrm{C} \mathrm{m}^{-2} \mathrm{~d}^{-1}$ in February, May and October, respectively. Whilst these values fall within the range of previously published community productivity rates for seagrass ecosystems (Jacobs 1979, Roman \& Able 1988, Pedersen \& Borum 1993, Johnson \& Johnstone 1995), they are nevertheless impressive considering the comparatively low standing crop of $Z$. noltii at the studied site (Table 1). The high ratios between total system respiration and gross community photosynthetic oxygen production rates, which ranged between $1: 1.64$ and $1: 2.82$, indicate that much of this fixed carbon is not remineralised in situ, but is exported from the system or buried in the sediments. Indeed, large quantities of detached $Z$. noltii leaves are removed almost on a daily basis from the beaches of the Bassin and the adjacent Atlantic coastline, and the export of biomass has been shown to be the major loss process in a subtidal Z. marina bed (Risgaard-Petersen et al. 1998).

Despite the relatively low water column DIN concentrations (Table 1), fluxes of DIN, nitrate and ammonium were large and always directed towards the sediment compartment throughout the year (Fig. 2). During both light and dark incubations, these fluxes were dominated by the $\mathrm{N}$-assimilation activity of the plant community, since removal of the Zostera noltii shoots essentially abolished nitrate fluxes and reversed ammonium fluxes, resulting in net effluxes of ammonium (Table 3) compared to high influxes of ammonium observed in the corresponding incubations with whole plants (Fig. 2). This regulation of DIN fluxes by the assimilatory capacity of the plants is also reflected by the magnitude of the fluxes during the different seasons, since the highest DIN fluxes coincided with the greatest standing crop of $Z$. noltii and the highest levels of gross community primary productivity, rather than the periods of elevated DIN concentrations in the water column (Fig. 2, Table 1). These observations are consistent with previous studies of subtidal seagrass beds (Moriarty \& Boon 1989, Caffrey \& Kemp 1992, Johnson \& Johnstone 1995, Risgaard-Petersen et al. 1998, Hansen et al. 2000), which have demonstrated a major influence of the seagrasses on both DIN and DON fluxes. For example, in a $Z$. marina bed 78 and $60 \%$ of total DIN fluxes determined in April and August, respectively, were at- 
tributed to the $\mathrm{N}$-assimilation activity of the seagrasses (Risgaard-Petersen et al. 1998).

Surprisingly, although fluxes of total DIN, nitrate and ammonium tended to be greater during light compared to dark incubations (Fig. 2), these differences were not significant $(\mathrm{p}>0.05)$ during any of the sampling periods. These data indicate that the Zostera noltii and the associated epiphyte community maintained a considerable assimilatory capacity for fixed-N during the dark period. In contrast, in subtidal $Z$. marina populations, DIN, nitrate and ammonium fluxes were between 2- and 6-fold greater during light compared to dark incubations (Risgaard-Petersen et al. 1998, Hansen et al. 2000). In marine micro- and macroalgae, high dark uptake rates of inorganic-N have been shown to be linked to N-limitation (Wheeler 1983, Lobban \& Harrison 1994). However, whilst Nlimitation may have influenced dark DIN uptake rates in summer and autumn (see below), this would appear extremely unlikely in February due to the relatively high water column DIN concentrations, the small $Z$. noltii standing crop and low primary productivity rates (Table 1, Fig. 1). Therefore, in the studied Z. noltii population, the high dark $\mathrm{N}$-assimilation capacity may represent an adaptation to the intertidal situation, since in this system the presence of the water column, and thus water column nutrient pools, does not always coincide with the photosynthetic period. Indeed, during periods of high water column turbidity, which are common in the lagoon following storm events (Auby 1991), periods of water column nutrient availability and the availability of sufficient light for net photosynthesis may be physically separated. Additionally, the plant community does not appear to show any significant assimilatory selection between the available inorganic- $N$ sources in the water column, as during all 3 sampling periods the relative composition of the DIN fluxes corresponded closely to the relative abundance of the inorganic-N species in the water column (Table 2 ). These data are in contrast to previous studies of $Z$. marina, which have indicated an assimilatory preference for ammonium in this species (Short \& McRoy 1984, Hemminga et al. 1994, Risgaard-Petersen et al. 1998).

Whilst it is somewhat difficult to assess the contribution of the DIN fluxes to the determined values of gross primary productivity, due to the intertidal nature of the sampling site and the uncertainty concerning the proportions of the primary productivity which are due to the seagrasses, their epiphytes and benthic microalgae. If we assume that the gross primary productivity was $50 \%$ due to the seagrasses and $50 \%$ due to other primary producers, which is not untypical of seagrass beds (Morgan \& Kitting 1984, Murray \& Wetzel 1987 , Moncreiff et al. 1992) and is in accordance with previ- ous studies of primary production in the Bassin D'Arcachon (Auby 1991), and a biomass N-content of $4.5 \%$, which is intermediate between that of seagrasses and micro-algae (Duarte 1990, 1992), then the N-demand for the rates of daily gross community productivity calculated previously would be 0.05 to $0.12,0.38$ to 0.82 and 0.20 to $0.49 \mathrm{~g} \mathrm{~N} \mathrm{~m}^{-2} \mathrm{~d}^{-1}$ in February, May and October, respectively, using a biomass C-content of $33 \%$ to convert the production data into grams dry weight. Since DIN fluxes were dominated by assimilation processes and not significantly different during light and dark incubations, if we take the average of the light and dark fluxes and a mean immersion period of $12 \mathrm{~h} \mathrm{~d}^{-1}$, which is typical for the seagrass meadows of the Ile aux Oiseaux (Auby \& Labourg 1996), then the DIN fluxes would be approximately equivalent to 0.16 , 0.28 and $0.11 \mathrm{~g} \mathrm{~N} \mathrm{~m}^{-2} \mathrm{~d}^{-1}$ for February, May and October, respectively. Thus, potentially, the measured DIN fluxes could supply 130 to 296,34 to 73 and 22 to $54 \%$ of the $\mathrm{N}$-demand for the gross system productivity rates determined for February, May and October respectively.

Previous studies of Zostera marina meadows have estimated that leaf uptake of DIN accounted for 60 to $70 \%$ (Hemminga et al. 1991), 40 to $76 \%$ (Pedersen \& Borum 1992), 68 to $92 \%$ (Hemminga et al. 1994) and $60 \%$ (Risgaard-Petersen et al. 1998) of the total nitrogen supply, percentages which are in good agreement with our estimations for May and October, but not February. However, it should be noted that in February the seagrass beds were covered by a mat of dead $Z$. noltii leaves, which was heavily colonised by diatoms. Thus, the comparatively low $Z$. noltii standing crop at this time (Table 1) probably meant that more than $50 \%$ of the overall community productivity was due to these micro-algae and, therefore, that the N-demand for primary productivity would have been greater than the value of $4.5 \%$ used in the calculation.

Similarly, the decomposition of these seagrass leaves may have created a net bacterial sink for inorganic-N, since, due to the large difference in the C:N ratios of the seagrass and bacterial biomasses, population increases in the decomposer community can create a bacterial assimilatory N-demand during the decomposition of high C:N substrates (Pedersen et al. 1999). Additionally, the assimilation and storage of $\mathrm{N}$ above their immediate growth requirements by the seagrasses and/or other members of the primary producer community (Chapman \& Craigie 1977, Pedersen \& Borum 1993, Viaroli et al. 1996) may also contribute to the apparent excess of N-supply compared to the calculated N-demand in February.

Biomass $\% \mathrm{~N}, \mathrm{C}: \mathrm{N}$ ratios and the composition of organic-N in the biomass of Zostera noltii and other seagrass species are known to fluctuate considerably 
with growth season (Pirc \& Wollenweber 1988, Pedersen \& Borum 1992), indicating that seagrasses are able to assimilate internal N-reserves during periods of low growth and high nutrient availability. Thus, these processes in concert could account for the apparent discrepancy between the DIN fluxes and calculated Nrequirements for primary productivity during this period. However, whilst the estimated figures must be considered with some caution due to the assumptions used for their calculation, they do indicate that in spring most, if not all, of the N-requirements of the seagrass community could have been supplied by the water column DIN pools. On the other hand, through summer into autumn the plants became increasingly dependent upon sediment N-pools, N-fixation and internal N-reserves for their growth requirements. This hypothesis of increasing N-limitation of the seagrasses throughout the growth season is supported by our N-fixation data (Fig. 4), with high rates and a strong light stimulation recorded in both May and October. Since, in these sediments, $\mathrm{N}$-fixation activity in the rhizosphere has previously been shown to be principally regulated by the plants, via a mutualistic association between the plant roots and N-fixing sulfate reducing bacteria (Welsh et al. 1996, 1997). The $\mathrm{N}$-fixation rates determined in this study were equivalent to $\mathrm{N}$-inputs to the sediments of between 2.0 and $4.7 \mathrm{mg} \mathrm{N} \mathrm{m}^{-2} \mathrm{~d}^{-1}$ or 0.5 to $3.7 \%$ of the calculated daily N-requirements for gross community primary productivity during the 3 sampling periods. These values are in general agreement with previous studies of an adjacent $Z$. noltii meadow (Welsh et al. 1996), where seasonal $\mathrm{N}$-fixation rates varied between 0.2 and $7.3 \mathrm{mg}$ $\mathrm{N} \mathrm{m}{ }^{-2} \mathrm{~d}^{-1}$ and were estimated to potentially supply between 6 and $12 \%$ of the annual $\mathrm{N}$-requirements for the net productivity of the seagrasses alone.

Rates of denitrification in the seagrass beds were extremely low and showed no significant seasonal trends. Denitrification of nitrate diffusing from the water column $\left(D_{\mathrm{W}}\right)$ was consistently below $2 \mu \mathrm{mol} \mathrm{N}$ $\mathrm{m}^{-2} \mathrm{~h}^{-1}$ (Fig. 3B) and represented only 0.1 to 0.7 and 0.2 to $1.3 \%$ of the total light and dark nitrate fluxes, respectively. But again, rates of $D_{\mathrm{W}}$ showed no significant seasonal trends although the water column nitrate concentration varied from 22.4 to $1.7 \mu \mathrm{M}$ between February and October (Table 1). These data are in contrast to those of a previous study in the Zostera noltii meadows (Rysgaard et al. 1996), where, although similarly low rates of denitrification were recorded during summer, a significant winter peak of $D_{\mathrm{W}}$, equivalent to 3.4 and $11.5 \mu \mathrm{mol} \mathrm{N} \mathrm{m} \mathrm{N}^{-2} \mathrm{~h}^{-1}$ during light and dark incubations, respectively, was recorded in January, when the water column nitrate concentration was $25.5 \mu \mathrm{M}$. However, our winter data may represent an anomaly, due to the presence of the mat of dead, diatom-colonised $Z$. noltii leaves, approximately $1 \mathrm{~cm}$ above the sediment surface. This diatom mat may have acted as a filter for nitrate diffusing towards the sediment and may also have increased the competition for nitrate between assimilatory and dissimilatory processes above the norm for this period. Whilst not significant, there was a tendency towards higher rates of $D_{\mathrm{w}}$ during dark incubations compared to light incubations (Fig. 3B). These data are in accord with previous studies of denitrification in other sediments (Risgaaard-Petersen et al. 1994, 1998, Rysgaard et al. 1994, 1995), which have demonstrated reduced rates of $D_{\mathrm{W}}$ in the light due to oxygen production by benthic micro-algae, which increase the oxygen penetration depth and thereby the diffusion path-length for nitrate to the denitrification zone, as well as increasing the competition between micro-phytobenthic $\mathrm{N}$-assimilation and denitrification for nitrate.

Similarly, rates of denitrification coupled to nitrification in the sediment $\left(D_{\mathrm{N}}\right)$ were low (Fig. 3C) and showed no significant differences between the sampling dates. Rates of $D_{\mathrm{N}}$ were generally higher during dark incubations compared to light incubations, and this difference was significant $(p<0.05)$ during the May sampling programme. These data are in contrast to those for sediments colonised by micro-algae, where rates of $D_{\mathrm{N}}$ are generally found to be greater during light incubations, due to the stimulation of nitrification and thus coupled nitrification/denitrification by photosynthetic oxygen evolution by the micro-algae (Risgaard-Petersen et al. 1994, Rysgaard et al. 1994, 1995). The results of previous studies on rates of coupled nitrification/denitrification in the rhizosphere sediments of aquatic macrophytes are highly contradictory, with several authors reporting high rates, attributed to a stimulation of nitrification by radial oxygen release by the plant roots (e.g. Iizumi et al. 1980, Caffrey \& Kemp 1990, 1992, Risgaard-Petersen \& Jensen 1997, Ottosen et al. 1999), whereas other studies report very low or undetectable rates (e.g. Rysgaard et al. 1996, Ottosen et al. 1999). Thus, the influence of rooted macrophytes on nitrification and coupled nitrification/denitrification may be system and/or seagrass species specific, and may reflect the relative balance between the potential stimulation of nitrification due to root excretion of oxygen and the competition between the roots and the nitrifying and denitrifying bacteria for ammonium, nitrite and nitrate, respectively. Our observation of higher rates of $D_{\mathrm{N}}$ during dark incubations compared to light incubations, especially in summer, indicates that in this Zostera noltii meadow the competition between the roots and the bacteria for inorganic- $\mathrm{N}$ has a greater influence on rates of coupled nitrification/denitrification than the potential stimulation of nitrification by root oxygen excretion during the photosynthetic period. 
It should, however, be noted, that in seagrasscolonised sediments, due to oxygen release by the plant roots, the isotope pairing technique may underestimate rates of $D_{\mathrm{N}}$, as coupled nitrification/denitrification may occur in microzones deep in the rhizosphere, remote from the diffusion zone of the ${ }^{15} \mathrm{~N}$-nitrate tracer added to the water column (Nielsen 1992). Thus the rates of denitrification recorded in the present study must be considered to reflect values for the surficial sediments alone, as labelled nitrate would not penetrate sufficiently into the sediment to measure the coupled nitrification/denitrification associated with oxygen release by the plant roots in the deeper sediments (Nielsen 1992). The high densities of obligatory aerobic, chemolithotrophic, sulfur-oxidising bacteria $\left(10^{7}\right.$ to $10^{9}$ cells $\left.\mathrm{cm}^{3}\right)$ in the rhizosphere sediments of the sampling station (Schaub \& van Gemerden 1996) indicate that oxygen is at least periodically available in the deeper sediments, although in situ microelectrode profiling during the October sampling campaign failed to detect oxygen below 1 to $2 \mathrm{~mm}$ depth in these sediments over the entire tidal cycle (A. Barbanti, M. Bartoli \& P. Viaroli unpubl. data). However, whilst oxygen may be available in the rhizosphere of Zostera noltii, this does not appear to support significant rates of nitrification, as nitrifier populations determined at the same sampling site during the period August 1996 to November 1997 were consistently below 500 and 200 cells $\mathrm{cm}^{-3}$ of rhizosphere sediment for ammonium- and nitrite-oxidising bacteria, respectively (Riou 1998). Additionally, light incubations of cores containing intact $Z$. noltii, following additions of $1 \mathrm{mM}{ }^{15} \mathrm{~N}$-ammonium to the sediment porewater, showed no evidence of significant rates of coupled nitrification/denitrification in the deeper rhizosphere sediments (Rysgaard et al. 1996, authors' unpubl. data). Thus, it would appear that, at least in the studied Z. noltii meadow, coupled nitrification/denitrification is confined to the surficial sediments and therefore would be accurately determined by the isotope pairing technique (Nielsen 1992). This conclusion is also supported by recent studies of coupled nitrification/denitrification in the rhizosphere sediments of $Z$. marina, which reported only very low or undetectable rates (Risgaard-Petersen et al. 1998, Ottosen et al. 1999).

Despite the apparent lack of coupled nitrification/ denitrification in the deeper sediments, this process was a more important pathway for N-loss than denitrification of water column nitrates, with rates of $D_{\mathrm{N}}$ representing 52 to $77 \%$ (seasonal mean $67 \%$ ) of total denitrification rates, supporting the proposal of Seitzinger (1988) that coupled nitrification/denitrification is the more important denitrification process in aquatic sediments. However, in the studied seagrass beds denitrifi- cation was not a significant sink for inorganic-N; for example, if our denitrification rates are considered typical of the $70 \mathrm{~km}^{2}$ of seagrass meadows, then denitrification losses account for $<3 \mathrm{t} \mathrm{N} \mathrm{yr}^{-1}$. On the other hand, annual $\mathrm{N}$-inputs to the Bassin d'Arcachon are estimated to be approximately $1500 \mathrm{t} \mathrm{N} \mathrm{yr}^{-1}$, and have increased by approximately $300 \mathrm{t} \mathrm{N} \mathrm{yr}^{-1}$ since 1970 due to nitrate run-off associated with the extension of intensive maize farming within the catchment (Auby et al. 1994). Thus, denitrification in the seagrasscolonised areas, which represent approximately 50\% of the total surface area of the Bassin, has only a negligible role in alleviating anthropogenic eutrophication. Additionally, N-losses via denitrification were more than balanced in all the tested seasons by $\mathrm{N}$-inputs from N-fixation (Fig. 4). Similarly, in temperate meadows of Zostera marina in Denmark, N-inputs from Nfixation have been reported to be greater than $\mathrm{N}$ losses due to denitrification (McGlathery et al. 1998, Risgaard-Petersen et al. 1998), and high rates of N-fixation in the rhizosphere are a common characteristic of seagrass meadows, and can significantly contribute to the N-requirements for primary production (O'Donohue et al. 1991, Moriarty \& O'Donohue 1993, Welsh 2000). In Arcachon, the comparatively high rates of Nfixation compared to denitrification rates resulted in net inputs of molecular nitrogen ( $\mathrm{N}$-fixation - total denitrification) equivalent to from 20 to 30,140 to 220 and 120 to $160 \mu \mathrm{mol} \mathrm{N} \mathrm{m}{ }^{-2} \mathrm{~d}^{-1}$ in February, May and October, respectively.

However, in this intertidal seagrass meadow the imbalance between denitrification and $\mathrm{N}$-fixation rates is probably greater than the estimates calculated above, which are based solely on rates determined in the presence of a water column, due to the differential impacts of tidal exposure on the N-process rates. N-fixation rates would be expected to be unaffected by the tidal cycle, as the bulk of this process occurs in the rhizosphere sediments and $\mathrm{N}$-fixation rates measured in the presence and absence of a water column are similar (Fig. 4; Welsh et al. 1996, 1997). In contrast, rates of $D_{\mathrm{W}}$, which are dependent on nitrate diffusing from the water column, would inherently be limited during tidal exposure, when only a thin layer of water is trapped between seagrass leaves and the sediment. The influence of tidal exposure on $D_{\mathrm{N}}$ is more difficult to predict, due to the conflicting effects of both potentially stimulatory and inhibitory effects. Potentially, air exposure could stimulate nitrification rates due to increased oxygen penetration into the sediments and thereby increase rates of $D_{\mathrm{N}}$. Conversely, harsher environmental conditions during low tide, such as exposure to UV light, extremes of temperature or abrupt changes in salinity due evaporation or precipitation, could negatively effect nitrification rates in the surficial sediments 
(Henriksen \& Kemp 1988). Additionally, these inhibitory effects of tidal exposure would vary considerably both seasonally and with respect to the timing and duration of the exposure period. In the studied Zostera noltii meadow tidal exposure has been shown to have little effect on oxygen penetration into the sediments, probably due to the water layer trapped by the $Z$. noltii leaves acting as a diffusion barrier to atmospheric oxygen (A. Barbanti, M. Bartoli \& P. Viaroli unpubl. data). Therefore, due to the limitation of nitrification to the surficial sediments and the potentially negative effects of tidal exposure, it would seem unlikely that nitrification rates and hence rates of $D_{\mathrm{N}}$ would be any higher during tidal exposure than under inundated conditions.

Since, in this macro-tidal coastal lagoon, denitrification losses are low and counterbalanced by $\mathrm{N}$-inputs from N-fixation, the major loss processes for anthropogenic inputs of nitrogen would appear to be due to the assimilation of this nitrogen into biomass by the primary producers, and export of this biomass to the Atlantic Ocean, due to the strong tidal circulation and/or the burial of the biomass- $\mathrm{N}$ in the sediments. Such N-losses through export are consistent with Nbudgets determined in subtidal Zostera marina meadows, where $82 \%$ of the inorganic-N assimilated by the plants was estimated to be exported as shed leaves (Risgaard-Petersen et al. 1998). In the Bassin d'Arcachon, the net primary production of $Z$. noltii alone has been conservatively estimated at $36000 \mathrm{t}$ dry wt $\mathrm{yr}^{-1}$ (Auby \& Labourg 1996), which is equivalent to 720 t N $\mathrm{yr}^{-1}$ considering a mean biomass $\mathrm{N}$-content of around $2 \%$ dry wt. Therefore, the export of $Z$. noltii and other primary producer biomasses potentially represents a major loss pathway for the large anthropogenic Ninputs to this macro-tidal lagoon and could substantially reduce internal $\mathrm{N}$-loading. This mechanism may have protected the seagrass meadows against the eutrophication-associated habitat losses which have been recorded throughout the world (see Duarte 1995, Hemminga 1998 for reviews), since, despite the increased N-loads to the Bassin d'Arcachon, there has been no change in the surface area occupied by the seagrass meadows (Auby et al. 1994, Auby \& Labourg 1996).

Acknowledgements. The authors wish to thank Guy 'le pere' Ollivier and his faithful vessel the 'Planula II' for assistance with sampling at the Ile aux Oiseaux, and Prof. Pierre Caumette for the use of laboratory facilities at the Laboratoire d'Océanographie, Arcachon. S.A.R. was supported by a grant from IFREMER-UMR 13 and Region Aquitaine. This work is a contribution to the ELOISE programme (ELOISE No. 161) within the framework of the NICE (Grant No. MAS3-CT960048) and ROBUST (Grant No. ENV4-CT96-0218) projects.

\section{LITERATURE CITED}

APHA (American Pharmaceutical Association) (1975) Standard methods for the examination of water and wastewaters, 14th edn. APHA, Washington, DC

Auby I (1991) Contribution à l'étude des herbiers de Zostera noltii dans le Bassin d'Arcachon: dynamique, production et dégradation, macrofaune associée. $\mathrm{PhD}$ thesis, Université de Bordeaux

Auby I, Labourg PJ (1996) Seasonal dynamics of Zostera noltii Hornem. in the Bay of Arcachon (France). J Sea Res 35: 269-277

Auby I, Manaud F, Maurer D, Trut G (1994) Etude de la prolifération des algues vertes dans le Bassin d'Arcachon. Rapport IFREMER-CEMAGREF-SSA-SABARC, IFREMER-Arcachon

Blackburn TH, Nedwell DB, Wiebe WJ (1994) Active mineral cycling in a Jamaican seagrass sediment. Mar Ecol Prog Ser 110:233-239

Burkholder JM, Glasgow HB, Cooke JE (1994) Comparative effects of water-column nitrate enrichment on eelgrass Zostera marina, shoalgrass Halodule wrightii, and widgeongrass Ruppia maritima. Mar Ecol Prog Ser 105: 121-138

Caffrey JM, Kemp WM (1990) Nitrogen cycling in sediments with estuarine populations of Potamogeton perfoliatus and Zostera marina. Mar Ecol Prog Ser 66:147-160

Caffrey JM, Kemp WM (1991) Seasonal and spatial patterns of oxygen production, respiration and root-rhizome release in Potamogeton perfoliatus L. and Zostera marina L. Aquat Bot 40:109-128

Caffrey JM, Kemp WM (1992) Influence of the submerged plant, Potamogeton perfoliatus, on nitrogen cycling in estuarine sediments. Limnol Oceanogr 37:1483-1495

Cambridge ML, McComb AJ (1984) The loss of seagrasses in Cockburn Sound, Western Australia. I. The time course and magnitude of seagrass decline in relation to industrial development. Aquat Bot 20:229-243

Capone DG (1988) Benthic nitrogen fixation. In: Blackburn TH, Sørensen J (eds) Nitrogen cycling in coastal marine environments. John Wiley and Sons Ltd, Chichester, p 85-123

Chapman ARO, Craigie JS (1977) Seasonal growth in Laminaria longicruris: relation with dissolved inorganic nutrients and internal reserves of nitrogen. Mar Biol 40: 197-205

Duarte CM (1990) Seagrass nutrient content. Mar Ecol Prog Ser 67:201-207

Duarte CM (1992) Nutrient concentration of aquatic plants: patterns across species. Limnol Oceanogr 37:882-889

Duarte CM (1995) Submerged aquatic vegetation in relation to different nutrient regimes. Ophelia 41:87-112

Gotceitas V, Fraser S, Brown JA (1997) Use of eelgrass beds (Zostera marina) by juvenile Atlantic cod (Gadus morhua). Can J Fish Aquat Sci 54:1306-1319

Hansen JW, Pedersen A-GU, Bernsten J, Rønbøg IS, Hansen LS, Lomstein BA (2000) Photosynthesis, respiration, and nitrogen uptake by different compartments of a Zostera marina community. Aquat Bot 66:281-295

Harlin MM, Thorn-Miller B (1981) Nutrient enrichment of seagrass beds in a Rhode Island coastal lagoon. Mar Biol 65:221-229

Hemminga MA (1998) The root/rhizome system of seagrasses: an asset and a burden. J Sea Res 39:183-196

Hemminga MA, Harrison PG, van Lent F (1991) The balance of nutrient losses and gains in seagrass meadows. Mar Ecol Prog Ser 71:85-96 
Hemminga MA, Koutstaal BP, van Soelen J, Merks GA (1994) The nitrogen supply to intertidal eelgrass (Zostera marina). Mar Biol 118:223-227

Henriksen K, Kemp WM (1988) Nitrification in estuarine and coastal marine sediments. In: Blackburn TH, Sørensen J (eds) Nitrogen cycling in coastal marine environments. John Wiley and Sons Ltd, Chichester, p 207-249

Iizumi H, Hattori A, McRoy CP (1980) Nitrate and nitrite in interstitial waters of (Zostera marina) eelgrass beds. Mar Biol 66:59-65

Jacobs RPWM (1979) Distribution and aspects of the production and biomass of eelgrass beds Zostera marina L., at Roscoff, France. Aquat Bot 7:151-172

Johnson P, Johnstone R (1995) Productivity and nutrient dynamics of tropical seagrass communities in Puttalam Lagoon, Sri Lanka. Ambio 24:411-417

Koroleff F (1970) Direct determinations of ammonia in natural waters as indophenol blue. Information on techniques and methodology for seawater analysis. ICES Int Lab Rep 3: $19-22$

Lobban CS, Harrison PJ (1994) Seaweed ecology and physiology. Cambridge University Press, Cambridge

McGlathery KJ, Risgaard-Petersen N, Christensen PB (1998) Temporal and spatial variation in nitrogen fixation activity in the eelgrass Zostera marina rhizosphere. Mar Ecol Prog Ser 168:245-258

Moncrieff CA, Sullivan MJ, Daehnick AE (1992) Primary production dynamics in seagrass beds of Mississippi Sound: the contributions of seagrass, epiphytic algae, sand microflora, and phytoplankton. Mar Ecol Prog Ser 38: 161-171

Morgan MD, Kitting CL (1984) Productivity and utilisation of the seagrass Halodule wrightii and its attached epiphytes. Limnol Oceanogr 29:1066-1076

Moriarty DJW, Boon PI (1989) Interactions of seagrasses with sediment and water. In: Larkum AWD, McComb AJ, Shepard SA (eds) Biology of seagrasses. Elsevier, Amsterdam, p 500-535

Moriarty DJW, O'Donohue J (1993) Nitrogen fixation in seagrass communities during summer in the Gulf of Carpentaria, Australia. Aust J Mar Freshw Res 44:117-125

Moriarty DJW, Roberts DG, Pollard PC (1990) Primary and bacterial productivity of tropical seagrass communities in the Gulf of Carpentaria, Australia. Mar Ecol Prog Ser 61: 145-157

Murray L, Wetzel RL (1987) Oxygen production and consumption associated with the major autotrophic components in two temperate seagrass communities. Mar Ecol Prog Ser 38:231-239

Neuendorfer JV, Kemp WM (1993) Nitrogen versus phosphorus enrichment of brackish waters: response of the submerged plant Potamogeton perfoliatus and its associated algal community. Mar Ecol Prog Ser 94:71-82

Nielsen LP (1992) Denitrification in sediment determined from isotope pairing. FEMS Microbiol Ecol 86:357-362

O'Donohue MJ, Moriarty DJW, McRae IC (1991) Nitrogen fixation in sediments and the rhizosphere of the seagrass Zostera capricornia. Microb Ecol 22:53-64

Ottosen LDM, Risgaard-Petersen N, Nielsen LP (1999) Direct and indirect measurements of nitrification and denitrification in the rhizosphere of aquatic macrophytes. Aquat Microb Ecol 19:81-91

Pedersen AGU, Berntsen J, Lomstein BA (1999) The effect of eelgrass decomposition on sediment carbon and nitrogen cycling: a controlled laboratory experiment. Limnol Oceanogr 44:1978-1992

Pedersen MF, Borum J (1992) Nitrogen dynamics of eelgrass
Zostera marina during a late summer period of high growth and low nutrient availability. Mar Ecol Prog Ser 80: 65-73

Pedersen MF, Borum J (1993) An annual nitrogen budget for a seagrass Zostera marina population. Mar Ecol Prog Ser 101:169-177

Pedersen O, Borum J, Duarte CM, Fortes MD (1998) Oxygen dynamics in the rhizosphere of Cymodocea rotundata. Mar Ecol Prog Ser 169:283-288

Pirc H, Wollenweber B (1988) Seasonal changes in nitrogen, free amino acids, and $\mathrm{C} / \mathrm{N}$ ratio in Mediterranean seagrasses. PSZN I: Mar Ecol 9:167-179

Riou SA (1998) Cycle de l'azote à l'interface eau-sédiment dans le Bassin d'Arcachon: rôle des bactéries dans les processus de perte en azote (nitrification-dénitrification). $\mathrm{PhD}$ thesis, Université Bordeaux I

Risgaard-Petersen N, Jensen K (1977) Nitrification and denitrification in the rhizosphere of the aquatic macrophyte Lobelia dortmanna L. Limnol Oceanogr 42:529-537

Risgaard-Petersen N, Rysgaard S, Nielsen LP, Revsbech NP (1994) Diurnal variation of denitrification in sediments colonised by benthic microphytes. Limnol Oceanogr 39: 573-579

Risgaard-Petersen N, Dalsgaard T, Rysgaard S, Christensen PB, Borum J, McGlathery K, Nielsen LP (1998) Nitrogen balance of a temperate eelgrass Zostera marina bed. Mar Ecol Prog Ser 174:281-291

Rizzo WM, Dailey SK, Lackey GJ, Christian RR, Berry BE, Wetzel RL (1996) A metabolism based trophic index for comparing the ecological values of shallow water sediment habitats. Estuaries 19:247-256

Roman CT, Able KW (1988) Production ecology of eelgrass (Zostera marina L.) in a Cape Cod salt marsh-estuarine system, Massachusetts. Aquat Bot 32:353-363

Rysgaard S, Risgaard-Petersen N, Sloth NP, Jensen K, Nielsen LP (1994) Oxygen regulation of nitrification and denitrification in freshwater sediments. Limnol Oceanogr 39:1643-1652

Rysgaard S, Christensen PB, Nielsen LP (1995) Seasonal variation in nitrification and denitrification in estuarine sediment colonized by benthic microalgae and bioturbating infauna. Mar Ecol Prog Ser 126:111-121

Rysgaard S, Risgaard-Petersen N, Sloth NP (1996) Nitrification, denitrification, and nitrate ammonification in sediments of two coastal lagoons in southern France. Hydrobiologia 329:133-141

Sand-Jensen K, Borum J (1991) Interactions among phytoplankton, periphyton, and macrophytes in temperate freshwater and estuaries. Aquat Bot 41:137-175

Schaub BEM, van Gemerden H (1996) Sulfur bacteria in sediments of two coastal ecosystems: the Bassin d'Arcachon and the Etang du Prévost, France. Hydrobiologia 329: $199-210$

Schramm W, Gualberto E, Orosco C (1984) Release of dissolved organic matter from marine tropical reef plants: temperature and desiccation effects. Bot Mar 27:71-77

Seitzinger SP (1988) Denitrification in freshwater and coastal marine ecosystems: ecological and geochemical significance. Limnol Oceanogr 33:702-724

Shieh WY, Yang JT (1997) Denitrification in the rhizosphere of the two seagrasses Thalassia hemprichii (Ehrenb.) Aschers and Halodule univervis (Forsk.) Aschers. J Exp Mar Biol Ecol 218:229-241

Short FT (1987) Effects of sediment nutrients on seagrasses: literature review and mesocosm experiment. Aquat Bot 27:41-57

Short FT, McRoy CP (1984) Nitrogen uptake by leaves and 
roots of the seagrass Zostera marina L. Bot Mar 27: $547-555$

Short FT, Burdick DM, Kaldy JE (1995) Mesocosm experiments quantify the effects of eutrophication on eelgrass, Zostera marina. Limnol Oceanogr 40:740-749

Sokal RR, Rohlf FJ (1995) Biometry. WH Freeman and Company, New York

Stevenson JC (1988) Comparative ecology of submersed grass beds in freshwater, estuarine, and marine environments. Limnol Oceanogr 33:867-893

Tomasko DA, Lapointe BE (1991) Productivity and biomass of Thalassia testudinum as related to water column nutrient availability and epiphyte levels: field observations and experimental studies. Mar Ecol Prog Ser 75:9-17

van Lent, Versschuure JM, van Veghel MLJ (1995) Comparative study on populations of Zostera marina L. (eelgrass): in situ nitrogen enrichment and light manipulation. J Exp Mar Biol Ecol 185:55-76

Viaroli P, Naldi M, Bondavalli C, Bencivelli S (1996) Growth

Editorial responsibility: Kenneth Heck (Contributing Editor), Dauphin Island, Alabama, USA of the seaweed Ulva rigida C. Agardh in relation to biomass densities, internal nutrient pools and external nutrient supply in the Sacca di Goro lagoon (northern Italy). Hydrobiologia 329:93-103

Welsh DT (2000) Nitrogen fixation in seagrass meadows: regulation, plant-bacteria interactions and significance to primary productivity. Ecol Lett 3:58-71

Welsh DT, Bourguès S, de Wit R, Herbert RA (1996) Seasonal variations in nitrogen fixation (acetylene reduction) and sulphate reduction rates in the rhizosphere of Zostera noltii: nitrogen fixation by sulphate reducing bacteria. Mar Biol 125:619-628

Welsh DT, Bourguès S, de Wit R, Auby I (1997) Effect of plant photosynthesis, carbon sources and ammonium availability on nitrogen fixation rates in the rhizosphere of Zostera noltii. Aquat Microb Ecol 12:285-290

Wheeler PA (1983) Phytoplankton nitrogen metabolism. In: Carpenter EG, Capone DG (eds) Nitrogen in the marine environment. Academic Press, New York, p 309-346

Submitted: March 1, 1999; Accepted: June 22, 2000

Proofs received from author(s): October 30, 2000 